\title{
CUT MOWING AND GRAZING EFFECTS WITH GREY CATTLE ON PLANT SPECIES COMPOSITION IN CASE OF PANNON WET GRASSLANDS
}

\author{
HÁzi, J. ${ }^{1}$-Penksza, K. ${ }^{1 *}$ - Bartha, S. ${ }^{2}$ - Hufnagel, L. ${ }^{3}$ - Tóth, A. ${ }^{1}$ - Gyuricza, Cs. ${ }^{4}-$ \\ SZENTES, SZ. ${ }^{4}$ \\ ${ }^{1}$ Department of Nature Conservation and Landscape Ecology, Szent István University \\ H-2103 Gödöllö, Páter K. 1. \\ (phone: +36-28-522-000, fax: +36-28-410-804) \\ ${ }^{2}$ Institute of Ecology and Botany of the Hungarian Academy of Sciences, \\ H-2163 Vácrátót, Alkotmány u 2-4., Hungary \\ ${ }^{3}$ Corvinus University of Budapest, Department of Mathematics and Informatics \\ 1118 Budapest, Villányi út 29-33 \\ (phone: +36-1-482-62-61; fax: +36-1/413-2881) \\ ${ }^{4}$ Institute of Plant Production, Szent István University \\ H-2103 Gödöllö, Páter K. 1. \\ (phone: +36-28-522-000, fax: +36-28-410-804) \\ *Corresponding author \\ e-mail:penksza@gmail.com \\ (Received $9^{\text {th }}$ March 2012; accepted $27^{\text {th }}$ March 2012)
}

\begin{abstract}
Examined area can be found at Balaton Uplands National Park (Hungary). 5 sample areas were examined in Badacsonytördemic: 1: 32 hectare under-grazed pasture, 2: 38 hectare overgrazed pasture, 3: 34 hectare hayfield, 4: trampled area, 5: beaten track. Livestock population was 118 in the monitored pastures. Sampling was executed along five $52 \mathrm{~m}$ long circular transects, within $5 \mathrm{~cm} \times 5 \mathrm{~cm}$ interlocking quadrates. Based on the data we can state that the curve of the drinking area was the highest of speciesarea examinations however weed appeared because of degradation which provided more species. According to species-area examinations overgrazed areas were richer in species then other examined areas. Based on diversity data drinking area considered degraded, while meadow and overgrazed areas was considered as proper state. Diversity of meadow was larger, but dominance of economically useful species was smaller. The amount of less valuable species - Carex hirta - increased.
\end{abstract}

Keywords: grazing, pasture, hayfield, species composition, nature conservation

\section{Introduction}

In Pannon region certain animal species bred because they can adapt to specific climatic conditions. Domestic grey cattle kept on wet grasslands, but it almost entirely disappeared from Hungarian steppes. Similar to the EU countries, heavy agrointensification was typical to Hungary between 1960 and 1980 and it ended in a similar way as other countries (Gregory et al., 2005). After the changing of regime productivity significantly fall back (Báldi and Faragó, 2007), which resulted of extensive areas and biodiversity (Tilman et al., 2002). This intensification process meant the use of more herbicides and chemical fertilizers and also the homogenization of landscape (Poschlod and WallisDeVries, 2002; Robinson and Sutherland, 2002; Benton et al., 2003; Tscharntke et al., 2005). The decreasing diversity is mainly depending on farm size 
because of management intensity at field scale. Positive effect were find in case of slope grassland topography while negative influence in case of farm size on species richness, orthopterans and butterflies (Marini et al., 2009). In EU countries agro-environmental programs were launched in order to stop or even reverse the decline of biodiversity (Kleijn and Sutherland, 2003). Payments to farmers were linked to ecological goods representing differently ranked quality-levels of vascular plant diversity (Kohyani et al., 2008; Klimek et al., 2008). In Hungary this effort was supported by the National Agroenvironmental Program (NAKP) and the 2253/1999 (X.7.) government decree (Haraszthy et al., 2004).

In Hungary grey cattle took into focus thank to the incentive of sustainable use of grasslands, it became decisive factor in grassland preservation under nature protection. Though grey cattle are kept extensively, livestock management methods are the same as in case of beef cattle. Contrary to the traditional grazing methods grey cattle can be kept on the pasture for a longer period (from April until November, 200-240 days). Demand of manpower is low and rotational grazing system proved to be the most effective. Besides the usability of grey cattle in nature conservation works, does not change the area compared other livestock area. Beef productivity per area depends not only on the performance of the animal but on the number of animal per area and utilization of pasture as well. There is negative correlation between the effectiveness of pasture usage and the production per animal. Positive correlation was examined between amount of ingestion and grass supply, if animals have the chance to select (Penning et al., 1986).

Grasslands are not only important from nature conservation aspects but they have economic importance as well. Therefore it is vital to know the species composition of the pastures. The aim of this survey is to find answers in this matter. In the sample area we examined the species combinations of the grassland, which is important for the survival of the grassland. Our question is how certain nature conservation methods, like mowing or grazing, change the inner structure of vegetation? Which method is the best for sustaining biodiversity, preserving the pasture considering nature conservation and economic aspects? It is important to know detailed composition of the area since the local interactions and the limited expansion determine dynamics of vegetation and set the rules of symbiosis for species (Durett and Levin, 1994; Tilman and Kareiva, 1997; Chesson, 2000). Environmental structures and management methods are determining factors in symbiotic processes. They can either strengthen or weaken symbiosis, depending on their conditions (Law et al., 2003; Bolker et al., 2003; Snyder and Chesson, 2004). Quality and diversity of the species combination around individual - so called neighbourhood diversity - is important from functional aspect as well (Oksanen, 1997). With the use of Juhász-Nagy model, micro-phytosociological landscape can be modelled. Fine-scale structure examinations can reveal diversity, structure of microhabitats (species combinations) and also the impacts of certain events on the vegetation which make nature conservation a more controllable task.

\section{Materials and methods}

\section{Sample areas}

Our sample area can be found near Balaton which is one of the richest regarding natural values in Hungary (Balaton Uplands National Park). The basin is surrounded by basalt peaks. There have always been intensive agricultural activities for centuries but 
the support programs after the changing of the regime changed and strengthened them. As result, grey cattle appeared in the region and now we can examine their effects.

Sample areas are in Badacsonytördemic:

1: 32 ha grassland space with low intensity grazing (under-grazed pasture)

2: 38 ha overgrazed pasture (space)

3: 34 ha meadow (hayfield)

4: trampled space near to the watering point

5: trodden path where animals go to drink etc., trampled space along the road

During examination 118 animals were found on pasture. Method of continuous grazing was applied. Agostio-Deschampsietum caespitosae Újvárosi 1947 associations were dominant on utilized areas, except for trodden parts next to the roads where LolioCynodontetum dactylidi Jarolímek et al. 1997 were typical. The examined area applied as pasture and meadow in the past.

\section{Phytosociological analysis}

The main purpose of this article to explore the condition of the grasslands regarding naturalism and degradation using fine-scale patterns based on micro-phytosociological examinations with the use of characteristic functions describing spatial structures (Juhász-Nagy and Podani, 1983). Samplings executed along five 52m long circular transects, within $5 \mathrm{~cm} \times 5 \mathrm{~cm}$ interlocking quadrates, where the presence of rooted species recorded. This sampling method provides detailed data about the condition of vegetation. It is relatively fast method and it causes insignificant disturbance (Bartha, 2001; Bartha et al., 2004). Complete sampling at each spatial-series step were executed, samples collected from all the possible positions in basic transects, allowing overlaps (Juhász-Nagy and Podani, 1983; Bartha and Kertész, 1998).

In order to avoid the artefacts - caused by stochastic behavior of rare species - whose frequency did not reached 3\% (Tóthmérész and Erdei, 1992). Theoretical and methodological basis for examination of crop micro-structure and the degeneration caused by disturbance - were provided by the models of Juhász-Nagy Pál (1993), Juhász-Nagy and Podani (1983) and their application methods (Bartha, 2001; Bartha and Kertész, 1998; Bartha et al., 1998, 2004; Campetella et al., 2004; Czárán and Bartha, 1989, 1992; Podani, 1993; Tóthmérész and Erdei, 1992).

Examined phytosociological status parameters were the followings: number of species, variance of species, number of species combinations, floral diversity, association and relative association. Variance of species refers to spatial heterogeneity. Number of species combinations shows the diversity of symbiosis and structural complexity of crop.

Detailed description of models and functions can be found in the works of JuhászNagy (1980, 1984), Juhász-Nagy and Podani (1983), Podani et al. (1993) and Bartha (2001).

\section{Results}

Couples of dominant species were found in the areas under disturbance or stress (drinking area $4^{\text {th }}$ stand, path $5^{\text {th }}$ stand). Their frequency was significant compared to the other species. Number of species which have $10 \%$ or higher frequency was low. In other stands, where disturbance was lower, there were more species with frequency higher then $10 \%$. 
Examining the number of species whose frequency is over 3\% in each spatial unit, we can see that the curves made around the trampled stand near to the watering point (stand 4), on the overgrazed area (stand 2), on the meadow, hayfield (stand 3) and on the under-grazed area (stand 1) reach the minimum area at $30 \mathrm{~m}, 40 \mathrm{~m}, 25 \mathrm{~m}$, and $45 \mathrm{~m}$ respectively. This means they contain all the species of at least $3 \%$ frequency (Fig. I). It means 16 species at the drinking area, 15 on the overgrazed area, 12 on the meadow and the under-grazed area and 2 along the road. The numbers of matrix species were: 5, 6, 6, 5 , 1. Along the road the only matrix species was Polygonum aviculare which explains the Fig. 1.

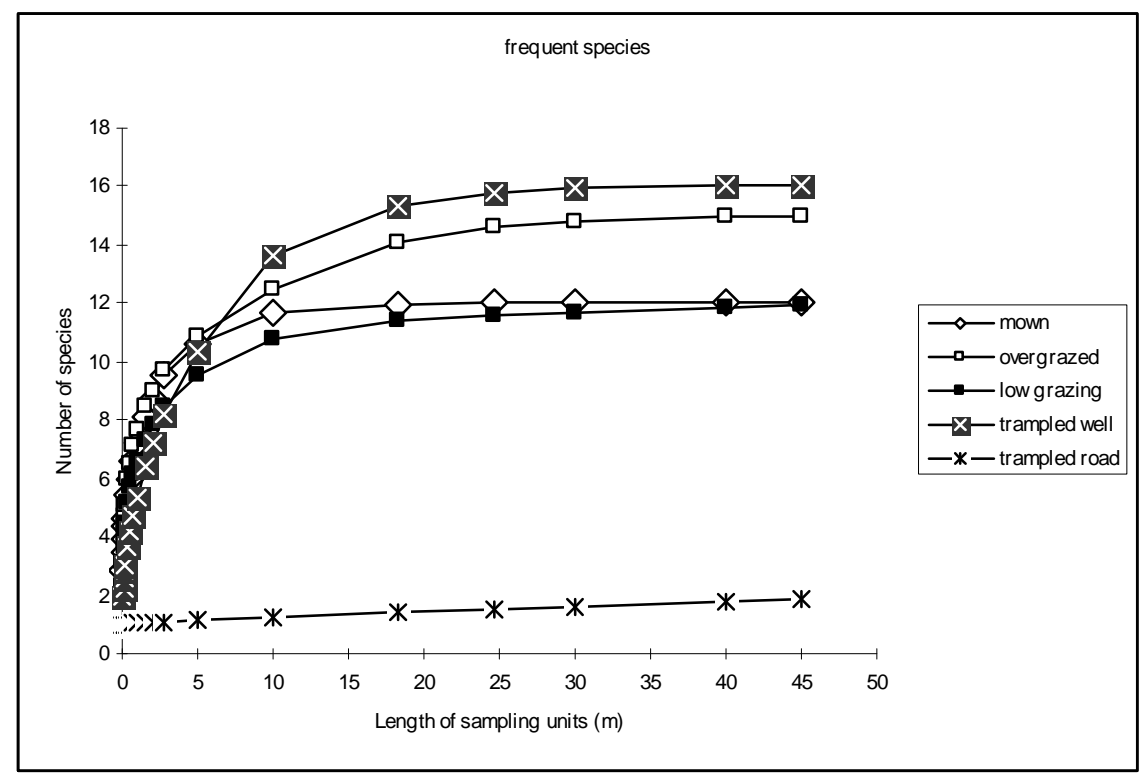

Figure 1. Variation in number of species at different spatial units in Badacsonytördemice sampling areas (species with frequency over 3\%) (Filled square: mown grassland; cross: overgrazed stand; star: grassland stand with low intensity grazing; $x$ : trampled stand near to the watering point; filled triangulum: trampled stand along the road.)

Variance in number of species refers to the amount of heterogeneity. Based on it and counted with finer spatial units significant differences were not found (Fig. 2). Low maximum were found of trampled stand curve along the road (5) and the high variance maximum of species number in the vegetation around the trampled stand near to the watering point (4). Maximums appeared along with big spatial units in both cases. Meadow showed the highest variance regarding species. These belongs to the useful grass-management category. Usage of small units, - $80 \mathrm{~cm}-5 \mathrm{~m}$ units - the under-grazed area showed the highest heterogeneity. 

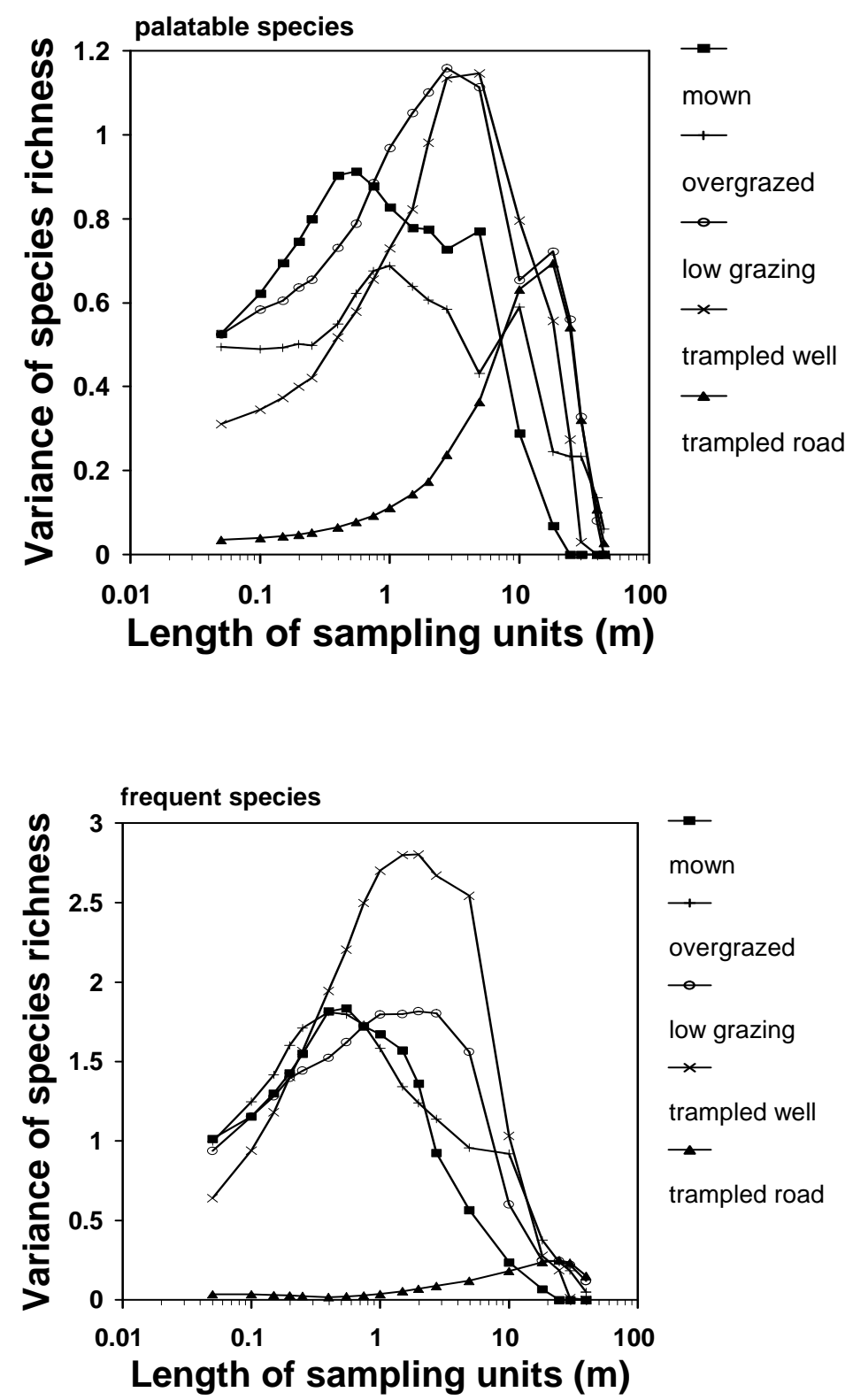

Figure 2. (2a and $2 b$ diagrams). changing of species number variance in sample areas of Badacsonytördemice regarding palatable and frequent (useful) species (Filled square: mown grassland; cross: overgrazed stand; star: grassland stand with low intensity grazing; $x$ : trampled stand near to the watering point; filled triangulum: trampled stand along the road.) 


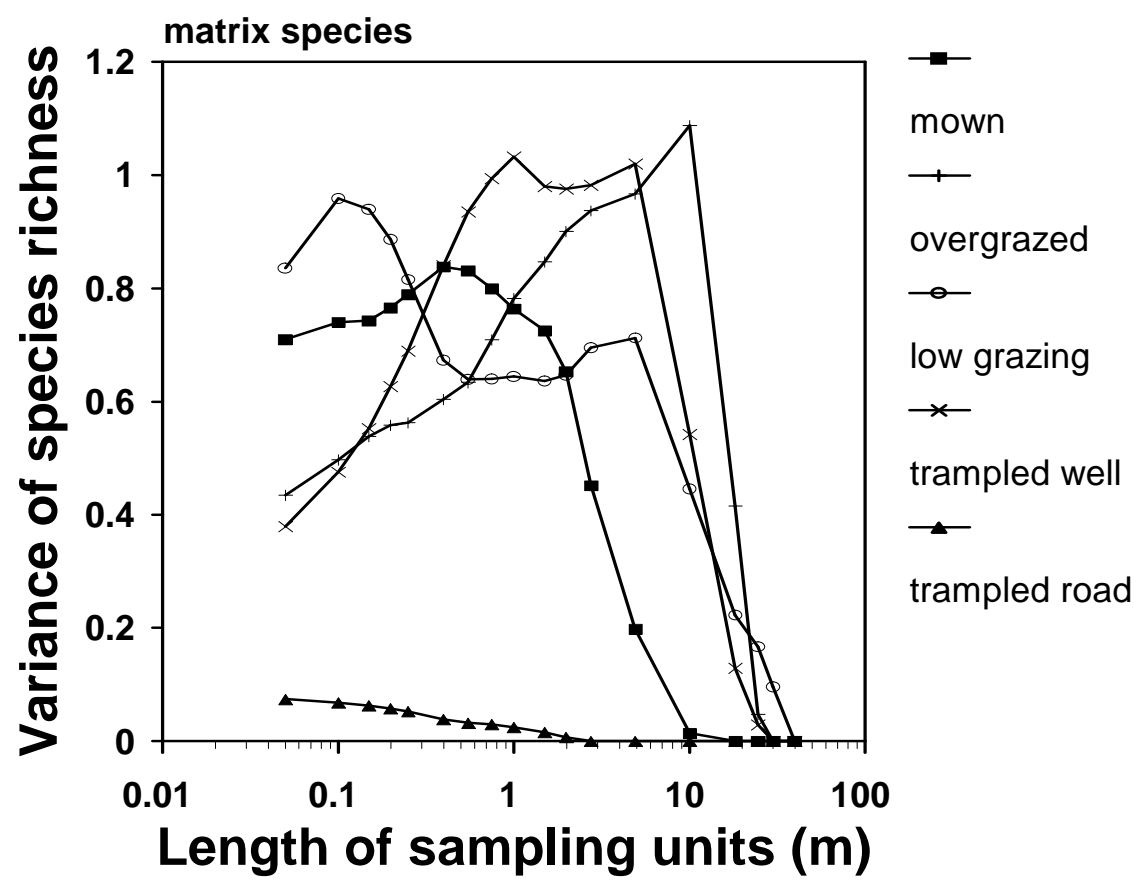

Figure 3. changing of species numbervariance in sample areas of Badacsonytördemice regarding matrix species (Filled square: mown grassland; cross: overgrazed stand; star: grassland stand with low intensity grazing; $x$ : trampled stand near to the watering point; filled triangulum: trampled stand along the road.)

Number of species combinations was the highest in the overgrazed area while application of $10 \mathrm{~cm}$ and $40 \mathrm{~cm}$ units in case of meadow was the best. This means that these unit sizes contain the most species combinations. Their curves later steeply decrease and it reached 0 at $30 \mathrm{~m}$. Matrix species showed the largest segregation in meadow (3) when $10 \mathrm{~cm}$ units were applied (Fig. 3). It is followed by the under-grazed area using the same quadrate size. Number of species combinations was the highest in case of meadows and overgrazed pastures at $10 \mathrm{~cm}$ and $40 \mathrm{~cm}$ scales respectively. It means that these scales represent the largest species combinations amongst examined associations. Afterwards their curves steeply decrease and they reached zero at $30 \mathrm{~m}$. The greatest separation was shown by the examination with matrix species (3). In case of meadow it appeared at $10 \mathrm{~cm}$ spatial unit which was followed by the under grazed area at the same quadrate unit.

\section{Discussion}

In the examined lines on the degraded areas, the number of species - with $10 \%$ frequency - was low compared to other areas. These species were mainly dominant gramineae and sedge species of the grasslands, which compose the basic texture of the vegetation. Other species fit into their matrix and the stability of the association depends on them. According to Kun et al. (2007) the steadiness of the dominance conditions show the stability of grassland (e.g.: in meadow and overgrazed areas), since in this case 
there are numerous species which can prevent the degradation of the structure if a dominant species disappear.

If we consider the primary and secondary gramineae and pulses important of grassland management aspects only, than the meadow curve $\left(3^{\text {rd }}\right.$ sample area) reaches its maximum only in $30 \mathrm{~m}$. Number of species of this line was six. Most of the taxa useful of grassland management aspects $(8 \mathrm{pcs})$ are in the overgrazed grassland.

Maximums of species variance also appeared on the mostly used, degraded areas. It refers to the homogeneity of vegetation (5), and to strong spatial heterogeneity. Besides matrix species- with small spatial units - grazed areas shows the highest species variance, namely spatial heterogeneity. It is also bad for the stability of species composition of grasslands. If we consider that the species belongs to the useful grassland management categories only, than meadow showed the highest variance, while - In $80 \mathrm{~cm}-5 \mathrm{~m}$ spatial unit - overgrazed area proved to be the most heterogeneous.

Number of species combinations indicates the diversity of symbioses methods between species and structural complexity of the association. Counting with all the species over 3\% appearance frequency, 1040 theoretical maximum did not occur in any cases. It would only be possible if there were different species combinations in all micro-quadrates. The most species combinations were found in meadow at small $10 \mathrm{~cm}$ spatial unit, this was followed by the under grazed area at the same quadrate unit.

Drinking area had the highest species-area examinations but weeds appeared to provide more species due to their degradation According to species-area examinations overgrazed areas were rich in species. Drinking area is considered degraded in case of compositional diversity, while meadow and overgrazed areas considered useful. Diversity of meadow was bigger, but the dominance of economically useful species was smaller and the amount of less valuable Carex hirta increased. It proves that mowing is a good method from nature protection aspects though it can ruin the feed value of the grass in long term. Regarding the matrix species, meadow has the best values thanks to the regular annual mowing. Second autumn mowing could be omitted. Due to the results of overgrazed areas summer and autumn increments should be grazed in order to maintain the species diversity of grassland and draw them into grassland cultivation method. .In case of meadow and overgrazed sample areas, mutual cultivation method used, since meadow was grazed for a shorter period at late summer or at fall in the previous years.

Production of sample area was significant so it could carry more species than the estimated animal carrying capacity. Due to the continuous burden grass can not reached significant height on the overgrazed area. Greater amount of feed produced because of continuous grazing results in greater production and continuous fertilization Contrary to the nature protection regulations, this specifies only 1 grey cattle per hectare while the area was capable to carry 3 animals. With this method utilization and sustainability regulations can be specified for a given area. It helps the directory of the national park to plan better nature protection actions. If they lead the animals to the under grazed area during dry period in August, it helps the regeneration of the grassland. Compositional diversity showed that the overgrazed area had a greater animal carrying capacity and its species composition was valuable from nature protection aspects.

In under grazed area, due to the lack of proper treatment, Festuca arundinacea which is a bog composing species which well adapts to extreme conditions - became dominant from species with feeding importance. Other species were present in low number. As a result of the lack of May-June mowing, number of species increased and 
grassland shifted toward "one-species" grassland. Its performance was high though animals did not like it. The species number and diversity was low. Prospect of becoming one-species grassland was a threat. Species composition on the overgrazed are seemed to be stable, number of grazing animals maintains the diversity of the grassland if their number was determined according to the distribution of the yield. Grazing compacted grass in overgrazed areas. Combination of useful species was examined in this study. It was good for the animal from health, fitness, etc. aspects if it grazed from different kind of species.

Acknowledgements. This work was supported by the Bolyai János Research Scholarship of MTA Doctoral Council, „ALÖKI” Applied Ecological Research and Forensic Institute Ltd., and the TÁMOP 4.2.1/B-09/1/KMR-2010-0005 project.

\section{REFERENCES}

[1] Báldi, A., Faragó S. (2007): Long-term changes of farmland game populations in a postsocialist country (Hungary). - Agriculture, Ecosystems \& Environment 118: 307-311.

[2] Bartha, S. (2001): Spatial relationships between plant litter, gopher disturbance, and vegetation at different stages of old-field succession. - Applied Vegetation Science 4: 5362 .

[3] Bartha, S., Kertész, M. (1998): The importance of neutral-models in detecting interspecific spatial associations from 'trainsect' data. - Tiscia 31: 85-98.

[4] Bartha, S., Campatela, G., Canullo, R., Bódis, J., Mucina, L. (2004): On the importance of fine-scale spatial complexit in vegetation restoration. - Int. J. Ecol. Environ. Sci. 30: 101-116.

[5] Bartha, S., Czárán, T., Podani, J. (1998): Exploring plant community dynamics in abstract coenostate spaces. - Abstracta Botanica 22: 49-66.

[6] Benton, T.G., Vickery, J.A., Wilson, J.D. (2003): Farmland biodiversity: is habitat heterogeneity the key? - Trends in Ecology and Evolution 18: 182-188.

[7] Bolker, B.M., Pacala, S.W., Neuhauser, C. (2003): Spatial dynamics in model plant communities: what we really know? - Am. Nat. 162: 135-148.

[8] Braun-Blanquet, J. (1964): Pflanzensoziologie 3. - Aufl. Wien, Springer-Verlag.

[9] Campetella, G., Canullo, R., Bartha, S. (2004): Coenostate descriptors and spatial dependence in vegetation $Ð$ derived variables in monitoring forest dynamics and assembly rules. - Community Ecology 5: 105-114.

[10] Chesson, P. (2000): Mechanisms of maintenance of species diversity. - Annu. Rev. Ecol. Syst. 31: 343-366.

[11] Czárán, T., Bartha, S. (1989): The effect of spatial pattern on community dynamics: a comparison of simulated and field data. - Vegetatio 83: 229-239.

[12] Czárán, T., Bartha, S. (1992): Spatiotemporal dynamic models of plant populations and communities. - TREE 7: 38-42.

[13] Durett, R., Levin, S.A. (1994): The importance of being discrete (and spatial). - Theor. Pop. Biol. 46: 363-394.

[14] Gregory, R.D., van Strien, A., Vorisek, P., Meyling, A. W.G., Noble, D.G., Foppen, P.B., Gibbons, D.W. (2005): Developing indicators for European birds. - Philosophical Transactions of the Royal Society Biological Sciences 360: 269-288.

[15] Haraszthy, L., Ángyán, J., Podmaniczky, L., Vajnáné, M.A. (2004): Nemzeti Vidékfejlesztési Terv Érzékeny Természeti Területek Programja 2004, Tájékoztató gazdálkodóknak. 
[16] Juhász-Nagy, P. (1984): Spatial dependence of plant populations. Part 2. A family of new models. - Acta. Bot. Acad. Sci. Hung. 30: 363-402.

[17] Juhász-Nagy, P. (1993): Notes on compositional divesity. - Hydrobiologia 249: 173-182.

[18] Juhász-Nagy, P., Podani, J. (1993): Information theory metods for the study of spatial processes is succession. - Vegetatio 51: 129-140.

[19] Kleijn, D., Sutherland, W.J. (2003): How effective are European agri-environment schemes in conserving and promoting biodiversity? - Journal of Applied Ecology 40: 947-969.

[20] Klimek, S., Richter, gen. Kemmermann, A., Steinmann, H-H., Freese, J., Isselstein, J. (2008): Rewarding farmers for delivering vascular plant diversity in managed grasslands: A transdisciplinary case-study approach. - Biological Conservation 141: 2888-2897.

[21] Kohyani, P.T., Bossuyt, B., Bonte, D., Hoffmann, M. (2008): Grazing as a management tool in dune grasslands: Evidence of soil and scale dependence of the effect of large herbivores on plant diversity. - Biological Conservation 141: 1687-1694.

[22] Kun, A., Ruprech, E., Bartha, S., Szabó, A., Virágh, K. (2007): Az Erdélyi Mezőség kincse: a gyepvegetáció egyedülálló gazdagsága. - Kitaibelia, 93-104.

[23] Law, R., Murrell, D.J., Dieckmann, U. (2003): Population growth in space and time: spatial logistic equations. - Ecology 84: 252-262.

[24] Marini, L., Fontana, P., Klimek, S., Battisti, A., Gaston, K.J. (2009): Impact of farm size and topography on plant and insect diversity of managed grasslands in the Alps. Biological Conservation 142(2):394-403.

[25] Oksanen, J. (1997): Plant neighbour diversity. - Journal of Vegetation Sciences 8: 255258.

[26] Penning, P.D., Hooper, G.E., Treacher, T.T. (1986): The effect of herbage allowances on intake and perfomance of ewes suckling twin lambs. - Grass and Forage Science 41: 199208.

[27] Podani, J. (1993): SYN-TAX 5.0 - computer programs for multivariate data analysis in ecology and systematics. - Abstracta Botanica 17: 289-302.

[28] Podani, J., Czárán, T., Bartha, S. (1993): Pattern, area and diversity: the importance of spatial scale in species assemblages. - Abstracta Botanica 17: 289-302.

[29] Poschlod, P., WallisDeVries, M.F. (2002): The historical and socioeconomic prospective of calcareous grasslands-lessons from the distance and recent past. - Biological Conservation 104: 361-376.

[30] Robinson, R.A., Sutherland. W.J. (2002): Post-war changes in arable farming and biodiversity in Great Britain. - Journal of Applied Ecology 39: 157-176.

[31] Wilson, A.D., MacLoad, N.D. (1991): Overgrazing: present or absent? - Journal of Range Management 44(5): 475-482.

[32] Snyder, R.E., Chesson, P. (2004): How the spatial scales of dispersal, competiton, and environmental heterogeneity interact to affect coexistence. - Am. Nat. 164: 633-650.

[33] Tilman, D., Cassman, K.G., Matson, P.A., Naylor, R., Polasky, S. (2002): Agricultural sustainability and intensive production practices - Nature 418: 671-677.

[34] Tóthmérész, B., Erdei, Zs. (1992): The effect of dominancein information theory characteristics of plant communities - Abstrata Botanica 16: 43-47.

[35] Tscharntke, T., Klein, A.M., Kruess, A., Steffan-Dewenter, I., Thies, C. (2005): Landscape perspectives on agricultural intensification and biodiversity - ecosystem service management. - Ecology Letters 8: 857-874. 